\title{
Фактори ризику розвитку відстрочених рестенозів у пацієнтів 3 малим діаметром коронарних артерій після проведених рентген-ангіографічних процедур
}

\author{
Аксьонов Є. В., Головенко В. Б. \\ ДУ «Національний інститут серцево-судинної хірургії імені М. М. Амосова НАМН» (Київ)
}

\begin{abstract}
Робота присвячена вивченню факторів ризику розвитку відстрочених рестенозів у пацієнтів із малим діаметром коронарних артерій після проведених рентген-ангіографічних процедур.

В дослідження ввійшло 315 пацієнтів віком $66,96 \pm 1,81$ років, із середнім діаметром істинного внутрішнього просвіту артерій 2,53 $\pm 0,011$ мм, яким була проведена реваскуляризація міокарда за допомогою стентування або шляхом перкутанної транслюмінальної балонної ангіопластики.

В результаті проведених досліджень встановлено, що кореляційна залежність між розвитком рестенозу КА і такими факторами, як артеріальна гіпертензія, дисліпідемія, куріння, наявність постінфарктного кардіосклерозу, була відсутня $\left(\mathrm{r}^{2}<0,1\right)$.

При супутньому цукровому діабеті рестеноз артерії в стенті виникав достовірно частіше $\left(\mathrm{r}^{2}=0,85\right)$, при цьому тип цукрового діабету на частоту рестенозу не впливав $\left(\mathrm{r}^{2}<0,1\right)$. У подібного контингенту хворих зростання довжини оклюзії більше 10 мм було достовірним фактором, що впливає на рестенозування КА у відстроченому періоді після проведеного стентування.

На розвиток рестенозу стентованої артерії, як і у пацієнтів, які перенесли ПТКА, не впливали такі фактори, як кількість уражених артерій, рівень ураження, наявність звивистості стентованої ділянки, залучення в стеноз біфуркації/гирла судини, форма атеросклеротичної бляшки, дисекція інтими артерії після «предилатації» та імплантації стента $\left(\mathrm{r}^{2}<0,1\right)$.

На частоту рестенозу після процедури стентування достовірно впливали такі фактори, як наявність колатерального кровотоку до процедури, вихідний морфологічний тип оклюзії, ступінь і довжина стенозу, кальциноз судини в місці втручання $\left(\mathrm{r}^{2}<0,01\right)$.

3 тактичних особливостей виконання стентування найгірший віддалений ангіографічний результат процедури показало застосування протеза меншого калібру, ніж просвіт артерії.
\end{abstract}

Ключові слова: коронарні артерії, рестеноз, рентген-ангіографічні процедури.

Натепер вважається загальновизнаним, що стентування та ангіопластика коронарних артерій (KА) є ефективними методами лікування ішемічної хвороби серця (IXC), що дозволяють у великому відсотку випадків досягти адекватного відновлення кровотоку у вінцевих судинах, уражених стенозуючим атеросклерозом.

В Україні щорічно проводиться близько 400 кардіохірургічних операцій на 1 млн. населення, що на кінець 2011 р. склало 17997 оперативних втручань (при потребі близько 35 тис.) [1]. При цьому кількість щорічних інтервенційних процедур становить більше 21 тис. при потребі у 200 тис. на рік [2, 3].

На сьогоднішній день кількість центрів, які виконують інвазивні серцеві втручання, у Європі становить 2,4 тис. В них виконується більше 4 тис. коронарографій і понад 1,5 тис. стентувань вінцевих артерій на 1 млн. населення [2]. У країнах Західної Європи та США балонна ангіопластика і стентування проводяться у $20-30 \%$ пацієнтів з IXC [2].
При цьому слід зазначити, що черезшкірні коронарні втручання здатні забезпечити адекватну реваскуляризацію міокарда [4] і значною мірою зменшити потребу в хірургічному коронарному шунтуванні, а в деяких пацієнтів стають повноцінною альтернативою аортокоронарному шунтуванню [5].

Однак незважаючи на впровадження нових технологій і методик в інтервенційній терапії IXC, використання сучасних стентів і балонів, розробку високоефективних методів фармакологічної підтримки процедури, уточнення показань до ії проведення та накопичення досвіду фахівців, відсоток дрібних і великих перипроцедуральних ускладнень при проведенні коронарних ангіопластик становить 3,9\% і 10,4\% відповідно [6].

Слід зазначити, що в науковій літературі наразі особлива увага приділяється питанню проведення ендоваскулярних реканалізацій у пацієнтів з малим діаметром коронарних артерій. Такий інтерес великою мі- 
рою зумовлений тим, що пацієнти з такими артеріями становлять значну частину популяції. Так, за даними багатьох авторів, від $30 \%$ до 50\% КА, які потребують стентування, мають діаметр менше 3 мм [7-9]. До того ж при ендоваскулярній реваскуляризації коронарних артерій малого діаметра у великому відсотку випадків спостерігаються рестенози стентованого сегмента i «великі» кардіальні ускладнення [8, 10, 11].

I дотепер не вирішеним залишається питання щодо вибору тактики реваскуляризації. Так, на думку M. P. Savage i співавт. [12] і згідно з даними «ISARSMART Trial» [13], стентування KA малого діаметру показало кращі клініко-ангіографічні результати порівняно з балонною ангіопластикою. Подібні результати були підтверджені і в більш пізньому дослідженні «PICCOLETO study» [14]. Проте в дослідженні S. Tanimoto з співавт. і у роботах $\mathrm{S}$. Rathore вказується, що імплантація стентів у коронарні судини малого діаметру не показало переваги перед балонною ангіопластикою артерій із діаметром менше 3 мм, а зазначена перевага зберігалася тільки при діаметрі артерії понад 2,6 мм $[15,16]$.

Таким чином, усі викладені вище факти диктують необхідність подальшого дослідження, систематизації, впровадження нових підходів у терапію та профілактику ускладнень, пов'язаних з інтервенційними процедурами у пацієнтів з IXC, що мають малий діаметр коронарних артерій.

Метою даної роботи було визначення факторів ризику розвитку відстрочених рестенозів у пацієнтів з малим діаметром коронарних артерій після проведених рентген-ангіографічних процедур.

Об'єкт і методи дослідження. У дослідження ввійшло 315 пацієнтів з IXC, яким на базі рентген-ангіографічного відділення Національного інституту серцево-судинної хірургії імені М. М. Амосова НАМН проводилися діагностичні та лікувальні інтервенційні процедури з приводу даної патології.

Пацієнтам досліджуваної групи було проведено 373 ангіографічні процедури на коронарних артеріях діаметром менше 3,0 мм. Вік пацієнтів коливався від 62 до 73 років (у середньому 66,96 $\pm 1,81$ років). Середня

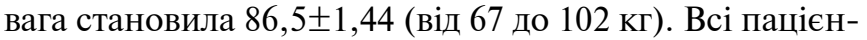
ти були обстежені згідно з протоколом, прийнятим у НІССХ імені М. М. Амосова НАМН для даної категорії хворих.

У пацієнтів, яким проводилося стентування КА $(\mathrm{n}=187)$, середній діаметр істинного внутрішнього

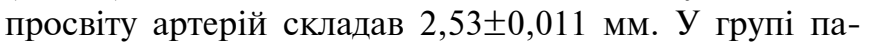
цієнтів, у яких використовувалася перкутанна транслюмінальна балонна ангіопластика (ПТКА) $(\mathrm{n}=128)$, даний показник визначався на рівні $2,61 \pm 0,09$ мм. Середній ступінь стенозу становив $81,3 \pm 4,07 \%$. Протяжність ураження дорівнювала 11,6 $\pm 0,73$ мм.
Bci хворі I групи мали в анамнезі Q-інфаркт міокарда (IM) давністю понад 3 місяці, що дозволило діагностувати у них постінфарктний кардіосклероз. Тривалість ішемічного анамнезу понад 5 років була відзначена у 26 хворих даної групи (8,25\% випадків), від 3 до 4 років - у 29 осіб (9,2\% випадків), від одного до двох років - у 39 пацієнтів (12,4\% випадків), до одного року - у 221 обстеженого (70,2\% випадків).

Переважною локалізацією IM була передня, верхівкова і передньобічна ділянка лівого шлуночка, що відповідало ішемії по басейну лівої коронарної артерії.

Слід особливо відзначити, що важка стенокардія III-IV класів (за функціональною класифікацією стенокардії Канадського серцево-судинного товариства) поєднувалася із серцевою недостатністю у 77,1\% обстежених хворих (243 пацієнив).

Результати досліджень та їх обговорення. Порівняльний аналіз даних у пацієнтів, яким проводилося стентування, показав, що кореляційна залежність між розвитком рестенозу КА і такими факторами, як артеріальна гіпертензія, дисліпідемія, куріння, наявність постінфарктного кардіосклерозу і т.д., була відсутня $\left(\mathrm{r}^{2}<0,1\right)$ (табл. 1).

Стан стентованої ділянки в даній групі не залежав від таких показників: вік пацієнта, тривалість IXC, фракція викиду міокарда, рівень холестерину, тригліцеридів $\left(\mathrm{r}^{2}<0,1\right)$ (табл. 1).

Достовірно частіше рестеноз артерії в стенті виникав при супутньому цукровому діабеті, що підтверджується достовірністю коефіцієнта кореляції $\left(\mathrm{r}^{2}\right)$ 0,85, що говорить про високий ступінь позитивної кореляційної залежності (табл. 1). При цьому тип цукрового діабету на частоту рестенозу не впливав $\left(\mathrm{r}^{2}<0,1\right)$.

У групі пацієнтів, яким була проведена транслюмінальна балонна ангіопластика, достовірна розбіжність з описаних вище показників була відсутня $(\mathrm{p}>0,1)$.

Порівняльний аналіз даних показав, що на розвиток рестенозу стентованої артерії, як і у пацієнтів, які перенесли ПТКА, не впливали такі фактори, як кількість уражених артерій, рівень ураження, наявність звивистості стентованої ділянки, залучення в стеноз біфуркації/гирла судини, форма атеросклеротичної бляшки, дисекція інтими артерії після «предилатації» та імплантації стента $\left(\mathrm{r}^{2}<0,1\right)$ (табл. 2).

Не було отримано достовірної відмінності щодо частоти відстроченого рестенозування КА і вихідного ï діаметра $(\mathrm{r}=0,043210)$ (рис. 1).

Слід зазначити, що у пацієнтів з ПТКА в групі відстроченого рестенозу переважали прооперовані зі складною морфологією вихідного ураження судин.

На частоту рестенозу після процедури стентування достовірно впливали: наявність колатерального кровотоку до процедури, вихідний морфологічний тип оклюзії, ступінь і довжина стенозу, кальциноз судини в місці втручання (табл. 3). 


\section{Таблиця 1}

Залежність частоти рестенозу від клінікоанамнестичних факторів у пацієнтів після стентування

\begin{tabular}{lccc} 
Фактори & $\begin{array}{c}\text { Рестено3 } \\
\text { (n=54) }\end{array}$ & $\begin{array}{c}\text { Відсутність } \\
\text { рестенозу } \\
\text { (n=133) }\end{array}$ & $\mathbf{r}^{2}$ \\
\hline Чоловіча стать & $46(85,2 \%)$ & $109(81,95 \%)$ & 0,0067 \\
\hline Вік >60 років & $21(38,9 \%)$ & $47(35,3 \%)$ & 0,0031 \\
\hline Тривалість ІХС >12 міс. & $28(51,9 \%)$ & $64(48,1 \%)$ & 0,0063 \\
\hline $\begin{array}{l}\text { Артеріальна } \\
\text { гіпертензія }\end{array}$ & $37(68,5 \%)$ & $93(69,9 \%)$ & 0,0018 \\
\hline Дисліпідемія & $33(61,1 \%)$ & $86(64,7 \%)$ & 0,0084 \\
\hline Куріння & $18(33,3 \%)$ & $48(36,1 \%)$ & 0,0034 \\
\hline $\begin{array}{l}\text { Постінфарктний } \\
\text { кардіосклероз }\end{array}$ & $27(50 \%)$ & $63(47,4 \%)$ & 0,074 \\
\hline $\begin{array}{l}\text { Стенокардія напру- } \\
\text { ження }\end{array}$ & $30(55,6 \%)$ & $69(51,9 \%)$ & 0,0021 \\
\hline $\begin{array}{l}\text { Нестабільна } \\
\text { стенокардія }\end{array}$ & $16(29,6 \%)$ & $42(31,6 \%)$ & 0,0042 \\
\hline ГІМ & $8(14,8 \%)$ & $22(16,5 \%)$ & 0,0067 \\
\hline Фракція викиду <50\% & $3(5,6 \%)$ & $11(8,3 \%)$ & 0,0016 \\
\hline $\begin{array}{l}\text { Холестерин } \\
>6,0 \text { ммоль/л }\end{array}$ & $28(51,9 \%)$ & $62(46,6 \%)$ & 0,0025 \\
\hline $\begin{array}{l}\text { Тригліцериди >2,0 } \\
\text { ммоль/л }\end{array}$ & $17(31,5 \%)$ & $49(36,8 \%)$ & 0,0072 \\
\hline $\begin{array}{l}\text { Цукор крові } \\
\text { >6,0 ммоль/л }\end{array}$ & $10(18,5 \%)$ & $7(5,3 \%)$ & 0,85 \\
\hline
\end{tabular}

Примітка: ГІМ - гострий інфаркт міокарда; $\mathrm{r}^{2}$ - коефіцієнт кореляції

\section{Таблиця 2}

Залежність частоти розвитку відстроченого рестенозу після імплантації стента від морфології вихідного ураження $K A$

\begin{tabular}{|c|c|c|c|}
\hline \multirow{7}{*}{ оаження >1-ї ав } & $\begin{array}{c}\text { Рестеноз } \\
(n=54)\end{array}$ & $\begin{array}{c}\text { Відсутність } \\
\text { рестенозу } \\
(\mathrm{n}=133)\end{array}$ & $r^{2}$ \\
\hline & $36(66,7 \%)$ & $92(69,2 \%)$ & 0,0017 \\
\hline & $18(33,3 \%)$ & $41(30,8 \%)$ & 0,0023 \\
\hline & $17(31,5 \%)$ & $56(42,1 \%)$ & 0,0041 \\
\hline & $10(18,5 \%)$ & $20(15 \%)$ & 0,0015 \\
\hline & 35 (64,8\%) & $82(61,7 \%)$ & 0,0037 \\
\hline & $2(3,7 \%)$ & $5(3,8 \%)$ & 0,001 \\
\hline
\end{tabular}

Примітка: $\mathrm{r}^{2}-$ коефіцієнт кореляції

У цій групі пацієнтів при складній морфології ураження (тип В2 і С за класифікацією АНА/АСС) рестенозування судин спостерігали достовірно частіше, ніж в інших випадках $(\mathrm{p}<0,001)$.

У пацієнтів, яким була виконана ПТКА, із зазначених вище причин достовірної відмінності не спостерігалося $(\mathrm{p}>0,1)$.

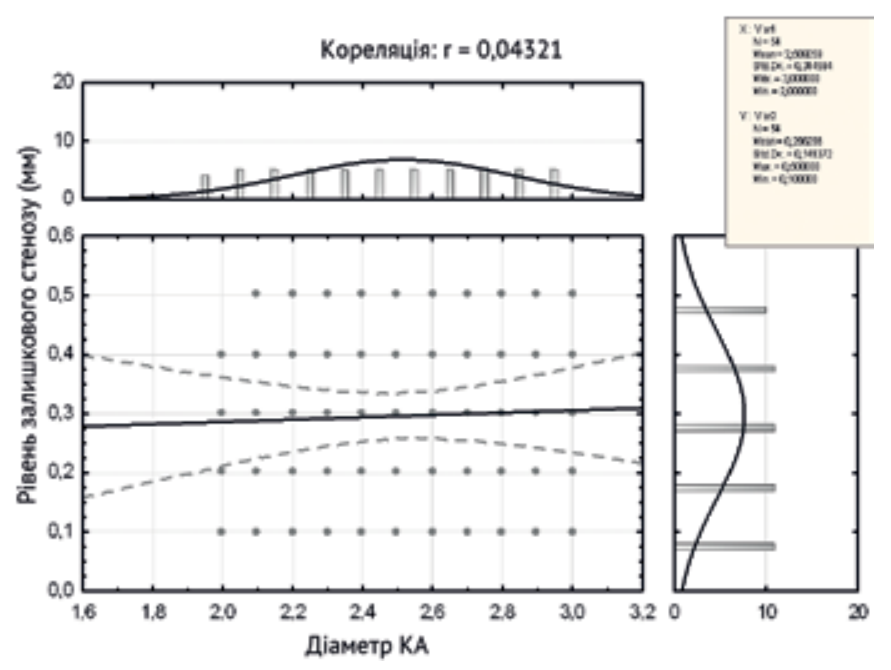

Рис. 1. Кореляційна залежність між частотою відстроченого рестенозування коронарних артерій та їх вихідного діаметра після імплантації стента (Примітка: КА - коронарна артерія; $r=0,043210$ )

\section{Таблиця 3}

Залежність частоти рестенозу після процедури стентування від вихідних ангіографічних факторів

\begin{tabular}{lccc} 
Фактори & $\begin{array}{c}\text { Рестеноз } \\
(\mathbf{n = 5 4 )}\end{array}$ & $\begin{array}{c}\text { Відсутність } \\
\text { рестенозу } \\
(\mathbf{n = 1 3 3 )}\end{array}$ & $\mathbf{r}^{2}$ \\
\hline Наявність колатералей & $10(18,5 \%)$ & $19(14,3 \%)$ & 0,0024 \\
\hline Ступінь стенозу $>70 \%$ & $37(68,5 \%)$ & $77(57,9 \%)$ & 0,0012 \\
\hline Оклюзія & $10(18,5 \%)$ & $20(15 \%)$ & 0,0033 \\
\hline Наявність кальцинозу & $18(33,3 \%)$ & $38(28,6 \%)$ & 0,0014
\end{tabular}

Примітка: $\mathrm{r}^{2}$ - коефіцієнт кореляції

Залежність частоти рестенозу від довжини вихідного ураження артерії після проведеного стентування представлена на рис. 2.

Як видно з рис. 2, у групі з рестенозом довші ураження (більше 10 мм) спостерігалися достовірно частіше, ніж локальні (менше 10 мм). Те саме засвідчив і кількісний аналіз даних: протяжність вихідного стенозу в разі повернення звуження становила в середньому $13,3 \pm 0,7$ мм, без нього $-11,2 \pm 0,4$ мм $(\mathrm{p}<0,006)$.

Порівняльний аналіз даних показав, що на розвиток рестенозу стентованих артерій не впливали величина тиску імплантації та тривалість імплантації стента, співвідношення його довжини з довжиною вихідного ураження $\left(\mathrm{r}^{2}<0,1\right)$ (табл. 4$)$.

Частота рестенозування достовірно залежала від розмірів стента, співвідношення його діаметра з істинним калібром артерії та способу імплантації. 
Аксьонов Є. В. / Фактори ризику розвитку відстрочених рестенозів у пацієнтів з малим діаметром...

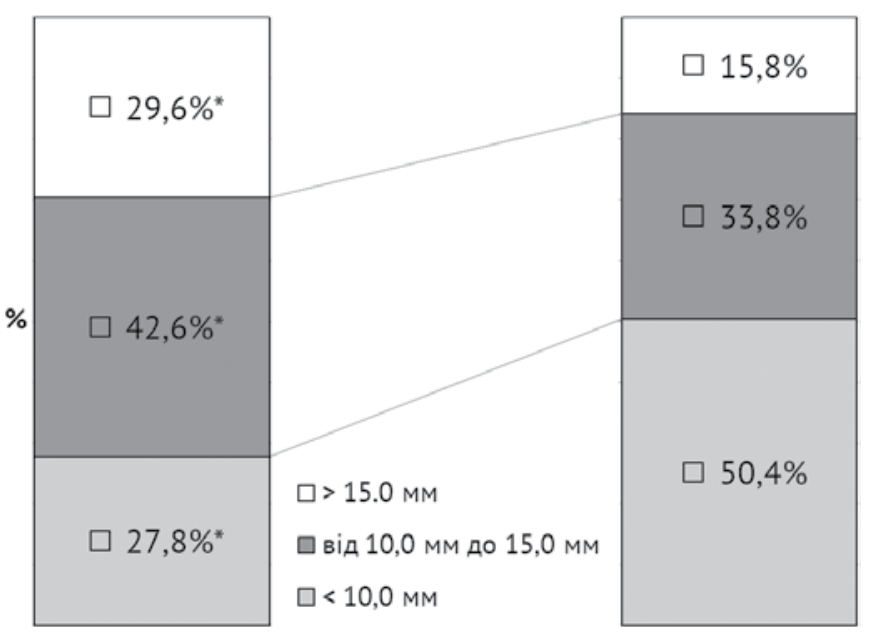

Рис. 2. Залежність частоти рестенозу від довжини вихідного ураження артерії після проведеного стентування (Примітка: * - p<0,05 у відповідній групі)

Таким чином, артерії з імплантованим стентом діаметром $<2,5$ мм частіше піддавалися рестенозуванню, ніж інші. Найменша частота повернення звуження відповідала протезам калібру 3,0 мм. За результатами кількісного аналізу даних, у групі з рестенозом діаметр стента становив у середньому $2,5 \pm 0,04$ мм, без нього $2,8 \pm 0,03$ мм $(\mathrm{p}<0,05)$.

3 тактичних особливостей виконання стентування найгірший віддалений ангіографічний результат процедури показало застосування протеза меншого калібру, ніж просвіт артерії.

При вивченні впливу тактичних особливостей виконання процедури ПТКА на розвиток рестенозу було визначено, що зазначені вище фактори на віддалений агіографічний результат балонної ангіопластики не впливали $(\mathrm{p}>0,1)$.

При виконанні попередньої балонної дилатації рестеноз складав $18(33,3 \%)$ випадків, при стентуванні «прямим» способом $-8(14,8 \%)(\mathrm{p}<0,01)$. Проведення «постдилатації» на частоту рестенозування не впливало $(\mathrm{p}>0,1)$.

Стан відновленої ділянки стентованої артерії суттево залежав від безпосереднього результату процедури: найменшу кількість рестенозів спостерігали при перевищенні досягнутим калібром протеза діаметрів прилеглих до нього незмінених відділів судини в середньому на $9,8 \pm 0,1 \%$, найбільше - при наявності залишкового стенозу артерії.

Подібна тенденція спостерігалася і при проведенні процедури ПТКА: достовірне зростання частоти рестенозу спостерігали в разі залишкового звуження артерії $>19,6 \pm 2,4 \%(\mathrm{p}<0,05)$.

Кількість випадків, при яких була відсутня різниця калібрів стентованої і прилеглої до стента ділянок

\section{Таблиця 4}

Залежність частоти рестенозу від тактичних особливостей процедури

\begin{tabular}{lccc} 
Фактори & $\begin{array}{c}\text { Рестено3 } \\
(\mathbf{n = 5 4 )}\end{array}$ & $\begin{array}{c}\text { Відсутність } \\
\text { рестенозу } \\
(\mathbf{n = 1 3 3 )}\end{array}$ & $\mathbf{r}^{2}$ \\
\hline Довжина стента >стенозу & $27(50 \%)$ & $60(45,1 \%)$ & 0,0014 \\
\hline Тиск імплантації >12 атм. & $31(57,4 \%)$ & $79(59,4 \%)$ & 0,0023 \\
\hline Тиск імплантації, атм. & $11,9 \pm 0,46$ & $11,6 \pm 0,21$ & 0,0015 \\
\hline Час імплантації, сек. & $44,9 \pm 1,20$ & $43,7 \pm 1,30$ & 0,0011
\end{tabular}

Примітка: $\mathrm{r}^{2}$ - коефіцієнт кореляції

судини, розподілилися в групах приблизно однаково. Тенденцію до збільшення частоти рестенозу спостерігали при перевищенні досягнутим діаметром артерії істинного (референтного) більш ніж на $10,3 \pm 0,2 \%$, при цьому повернення стенозу частіше виникало по краях протеза.

Перевищення калібром артерії діаметру стента негативно впливало на віддалений агіографічний результат процедури навіть при високому тиску імплантації протеза (більше 12 атм.).

Достовірне збільшення частоти рестенозу після проведеного стентування за наявності цукрового діабету спостерігали тільки у випадку процедури з приводу довгого ураження (більше 10 мм) КА. При цьому визначалася сильна негативна кореляція з коефіцієнтом $\mathrm{r}=-0,7906$. Тобто в пацієнтів із цукровим діабетом зростання довжини оклюзії більше 10 мм було достовірним фактором, що впливає на рестенозування КА у відстроченому періоді після проведеного стентування.

Подібна тенденція зростання кількості рестенозів у даній групі пацієнтів спостерігалася і при супутній гіперхолестеринемії ( $\mathrm{r}=-0,7804 ; \mathrm{p}=0,00001)$.

Частота рестенозу при співвідношенні діаметрів стента і артерії на користь судини також була найбільшою в разі протяжного ураження (більше 10 мм) KА $(\mathrm{p}<0,03)$.

\section{Висновки}

1. Кореляційна залежність була відсутня між розвитком рестенозу КА і такими факторами, як артеріальна гіпертензія, дисліпідемія, куріння, наявність постінфарктного кардіосклерозу $\left(\mathrm{r}^{2}<0,1\right)$.

2. Достовірно частіше рестеноз артерії в стенті виникав при супутньому цукровому діабеті $\left(\mathrm{r}^{2}=0,85\right)$, при цьому тип цукрового діабету на частоту рестенозу не впливав $\left(\mathrm{r}^{2}<0,1\right)$. У подібного контингенту хворих зростання довжини оклюзії більше 10 мм було достовірним фактором, що впливає на рестенозування КА у відстроченому періоді після проведеного стентування. 
3. На розвиток рестенозу стентованої артерії, як і у пацієнтів, які перенесли ПТКА, не впливали такі фактори, як кількість уражених артерій, рівень ураження, наявність звивистості стентованої ділянки, залучення в стеноз біфуркації/гирла судини, форма атеросклеротичної бляшки, дисекція інтими артерії після «предилатації» та імплантації стента $\left(\mathrm{r}^{2}<0,1\right)$.

4. На частоту рестенозу після процедури стентування достовірно впливали наявність колатерального кровотоку до процедури, вихідний морфологічний тип оклюзії, ступінь і довжина стенозу, кальциноз судини в місці втручання $\left(\mathrm{r}^{2}<0,01\right)$.

5. Із тактичних особливостей виконання стентування найгірший віддалений ангіографічний результат процедури показало застосування протеза меншого калібру, ніж просвіт артерії.

\section{Література}

1. Устинов А. В. Кардиохирургия и интервенционная кардиология: проблемы и перспективы развития / А. В. Устинов // Український медичний часопис. 2012. - № 1 (87). - C. 8-10.

2. Аналіз захворюваності на ішемічну хворобу серця в Україні / В. А. Гандзюк // Український кардіологічний журнал. - 2014. - № 3. - С. 45-52.

3. Коваленко В. М. Регіональні медико-соціальні проблеми хвороб системи кровообігу. Динаміка та аналіз / В. М. Коваленко, В. М. Корнацький. - К. : МОЗ України, ДУ «УІСД МОЗ України», 2013. - 239 с.

4. Comparison of coronary artery bypass grafting with percutaneous coronary intervention for unprotected left main coronary artery disease / D. Kawecki, B. Morawiec, M. Fudal [et al.] // Yonsei Med. J. - 2012. - Vol. 53, № 1. - P. 58-67.

5. Everolimus eluting stents versus coronary artery bypass graft surgery for patients with diabetes mellitus and multivessel disease / S. Bangalore, Y. Guo, Z. Samadashvili [et al.] // Circ. Cardiovasc. Interv. - 2015. - Vol. 8, № 7. - e002626.

6. Clinical, angiographic, and procedural predictors of periprocedural complications during chronic total occlusion percutaneous coronary intervention / V. G. Patel, T. T. Michael, O. Mogabgab [et al.] // J. Invasive Cardiol. 2014. - Vol. 26, № 3. - P. 100-105.

7. Miniaturized self-expanding drug-eluting stent in small coronary arteries: late effectiveness / F. R. Oliveira,
L. A. Mattos, A. Abizaid [et al.] // Arq. Bras. Cardiol. 2013. - Vol. 101, № 5. - P. 379-387.

8. Two-year safety and effectiveness of the platinum chromium everolimus-eluting stent for the treatment of small vessels and longer lesions / P. S. Teirstein, I. T. Meredith, R. L. Feldman [et al.] // Catheter. Cardiovasc. Interv. 2015. - Vol. 85, № 2. - P. 207-215.

9. A 2-year follow-up of a randomized multicenter study comparing a paclitaxel drug-eluting balloon with a paclitaxel-eluting stent in small coronary vessels the BELLO study / T. Naganuma, A. Latib, G. A. Sgueglia [et al.] // Int. J. Cardiol. - 2015. - Vol. 184. - P. 17-21.

10. An everolimus-eluting stent versus a paclitaxel-eluting stent in small vessel coronary artery disease: a pooled analysis from the SPIRIT II and SPIRIT III trials / A. L. Bartorelli, P. W. Serruys, K. Miquel-Hŭbert [et al.] // Catheter Cardiovasc. Interv. - 2010. - Vol. 76, № 1. - P. 60-66.

11. Long-term outcome in patients treated with sirolimuseluting stents in complex coronary artery lesions: 3-year results of the SCANDSTENT (Stenting Coronary Arteries in Non-Stress/Benestent Disease) trial / H. Kelbaek, L. Klwvgaard, S. Helqvist [et al.] // J. Am. Coll. Cardiol. 2008. - Vol. 51, № 21. - P. 2011-2016.

12. Efficacy of coronary stenting versus balloon angioplasty in small coronary arteries. Stent Restenosis Study (STRESS) Investigators / M. P. Savage, D. L. Fischman, R. Rake [et al.] // J. Am. Coll. Cardiol. - 1998. - Vol. 31, № 2. P. 307-311.

13. Comparative analysis of stent placement versus balloon angioplasty in small coronary arteries with long narrowings (the Intracoronary Stenting or Angioplasty for Restenosis Reduction in Small Arteries [ISAR-SMART] Trial) / J. Hausleiter, A. Kastrati, J. Mehilli [et al.] // Am. J. Cardiol. - 2002. - Vol. 89, № 1. - P. 58-60.

14. Paclitaxel-coated balloon versus drug-eluting stent during PCI of small coronary vessels, a prospective randomised clinical trial. The PICCOLETO study / B. Cortese, A. Micheli, A. Picchi [et al.] // Heart. - 2010. - Vol. 96, № 16. - P. 1291-1296.

15. Tanimoto S. Update on stents: recent studies on the TAXUS stent system in small vessels / S. Tanimoto, J. Daemen, P. W. Serruys // Vasc. Health Risk Manag. - 2007. - Vol. 3, № 4. - P. 481-490.

16. Rathore S. Small coronary vessel angioplasty: outcomes and technical considerations / S. Rathore // Vasc. Health Risk Manag. - 2010. - Vol. 6. - P. 915-922.

\section{Risk factors for the development of delayed restenosis in patients with low coronary artery diameter after performed X-ray angiographic procedures}

Aksenov E. V., Golovenko V. B.

National M. M. Amosov Institute of Cardiovascular Surgery National Academy of Medical Sciences of Ukraine (Kyiv)

The work is devoted to the study of risk factors for the development of delayed restenosis in patients with small diameter coronary arteries after performed X-ray angiographic procedures.

The study included 315 patients aged $66.96 \pm 1.81$ years, with a mean diameter of the true internal lumen of the arteries of $2.53 \pm 0.011 \mathrm{~mm}$, which had a revascularization of the myocardium through stenting or percutaneous transluminal balloon angioplasty (PTBA). 
As a result of the research, it was found that there was no correlation between the development of CA restenosis and such factors as: arterial hypertension, dyslipidemia, smoking, postinfarctional cardiosclerosis $\left(\mathrm{r}^{2}<0.1\right)$.

In case of concomitant diabetes mellitus, restenosis of the artery in the stent was significantly more frequent $\left(\mathrm{r}^{2}=0.85\right)$, while the type of diabetes did not affect the restenosis rate $\left(\mathrm{r}^{2}<0.1\right)$. In such a contingent of patients, the increase in the length of the occlusion of more than $10 \mathrm{~mm}$, was a reliable factor that affects the restenosis of the spacecraft in the postponed period after the stenting.

The development of restenosis of the stent artery, as well as in patients who have undergone (PTBA), was not affected by such factors as: the number of affected arteries, the degree of lesion, the presence of locomotor of the stented area, involvement in the bifurcation / vascular stenosis of the vessel, the form of the atherosclerotic plaque, dissection intima arteries after «predilyatation» and implantation of the stent $\left(\mathrm{r}^{2}<0,1\right)$.

The following factors, such as: the presence of collateral blood flow to the procedure, the initial morphological type of occlusion, the degree and length of stenosis, the calcinosis of the vessel at the site of intervention $\left(r^{2}<0,01\right)$, were strongly influenced by the restenosis frequency after the stenting procedure.

With the tactical features of stenting, the worst remote angiographic result of the procedure showed the use of a prosthetic smaller caliber than the lumen of the artery.

Key words: coronary artery, restenosis, $X$-ray angiographic procedures.

\section{Факторы риска отсроченных рестенозов у пациентов с малым диаметром коронарных артерий после проведенных рентген-ангиографических процедур}

\section{Аксенов Е. В., Головенко В. Б.}

ГУ «Национальный институт сердечно-сосудистой хирургии имени Н. М. Амосова НАМН» (Киев)

Работа посвящена изучению факторов риска развития отсроченного рестеноза у пациентов с коронарными артериями малого диаметра после проведения рентген-ангиографических процедур. Исследование включало 315 пациентов в возрасте 66,96 $\pm 1,81$ лет со средним диаметром истинного внутреннего просвета артерий $2,53 \pm 0,011$ мм, у которых применялась реваскуляризация миокарда путем стентирования или чрескожной транслюминальной баллонной ангиопластики (ЧТБА).

В результате исследования не обнаружено корреляции между развитием рестеноза в КА и такими факторами, как артериальная гипертензия, дислипидемия, курение, постинфарктный кардиосклероз $\left(\mathrm{r}^{2}<0,1\right)$. В случае сопутствующего сахарного диабета рестеноз артерии в стенте встречался значительно чаще $\left(\mathrm{r}^{2}=0,85\right)$, тогда как тип диабета не влиял на скорость развития рестеноза $\left(\mathrm{r}^{2}<0,1\right)$.

Сравнительный анализ данных показал, что на развитие рестеноза стентированной артерии у пациентов, которые перенесли ПТКА, не влияли такие факторы, как количество пораженных артерий, степень поражения, извитость стентированного участка, вовлечение в стеноз бифуркации/устья сосуда, форма атеросклеротической бляшки, диссекция интимы артерии после «предилатации» и имплантации стена $\left(\mathrm{r}^{2}<0,1\right)$.

На частоту рестеноза после процедуры стентирования достоверно влияли следующие факторы: наличие коллатерального кровотока до процедуры, исходный морфологический тип окклюзии, степень и длина стеноза, кальциноз сосуда в месте вмешательства $\left(\mathrm{r}^{2}<0,01\right)$.

Из тактических особенностей выполнения стентирования худший отдаленный результат процедуры показало использование протеза меньшего калибра, чем просвет артерии.

Ключевые слова: коронарные артерии, рестеноз, рентген-ангиографические процедуры. 